\title{
小児ネフローセ症候群患者に対する遺伝子組換え 人血清アルブミン製剂の使用経験
}

\author{
敦賀 和志・八代 知美 - 沖 栄真 - 田中 完 \\ (受付日 : 平成21年 7 月30日採用日 : 平成21年 8 月20日)
}

要旨

【はじめに】遺伝子組換え人血清アルブミン (rHSA) 製斉はピキア酵母を宿主とした組換え型人血清アルブミ ン製剂である。成人肝硬変症やネフローゼ症候群 (NS) 患者への投与報告は散見されるが , 小児患者への投与報 告は未だない。今回われわれは, 小児 NS に伴う浮腫に 対し rHSA を投与し, 主に弚の安全性を中心に検討し た。

【対象，方法】2008年 9 月から2009年1月までNSにて 当院で入院加療され, 浮腫, 尿量低下, 循環不全をきた し, 利尿剂のみでは症状の改善が得られない状態の患者 で同意が得られた 6 例（4〜17歳），延べ 8 例を対象と した。原疾患は, 微小変化型 3 例, 巣状系球体硬化症 2 例，紫斑病性腎炎 1例であり，当施設倫理委員会の承認 後に本斉の投与を開始した。投与法は一定ではなく個々 人の臨床状態により調整したことから，1日投与量は 4 〜37.5g，投与期間は 3〜22日であった。

【結果】本斉投与前の血清抗ピキア酵母 IgE 抗体はすべ ての症例で陰性であった。また，rHSA 投与後 $1 \sim 4$ 力 月での抗体か陽性化した者も認められず，繰り返し投与 によるアレルギー反応はみられなかった。いずれの症例 も浮腫の改善, 尿量の増加, 循環動態の安定が得られ, 血清アルブミン值も改善が認められた。

弘前大学医学部小览科

( ₹ 036-8562 弘前市在府町5)

Use of recombinant human serum albumin in pediatric patients with nephrotic syndrome

Kazushi Tsuruga , Tomomi Yashiro, E ishin Oki , Hiroshi Tanaka

Department of Pediatrics, Hirosaki University School of Medicine
【まとめ】今回のわれわれの検討からは, rHSA 製剤は 小児NS 患者の浮腫に対し安全に投与が可能であり，従 来の献血由来アルブミン製剂 (nHSA) の近い将来の代 替え療法としての可能性も示唆された。今後多数の症例 で長期間の検討が必要である。

\section{序言}

ネフローゼ症候群 (NS) は蛋白尿, 低蛋白血症, 浮 腫，高脂血症を呈する疾患である。浮腫改善のために ループ利尿薬が用いられることが多いが, 重度の低アル ブミン血症の場合，利尿剂に対し反応性に乏しいことを 経験する。このような症例は重度の浮腫を呈し，胸水や 腹水を認めることが多く，異論はあるものの一般臨床で は利尿剂に加えアルブミン製剂が用いられる。ヒト献血 由来アルブミン製剂 ( $\mathrm{nHSA})$ は，人血液を原料とする ためにプリオンや未知のウイルスといった感染性物質に よる安全性のリスクが常に付きまとゔ1。一方, 遺伝子 組換え人血清アルブミン製剂 (rHSA) の構造はnHSA 製剂と同等であり，光の製造過程において動物由来製剂 を用いておらず，感染性物質混入のお炎れがない2)。臨 床応用としては, 成人の肝硬変症に対して重度の副作用 がなく投与できたとする報告があり ${ }^{3 / 4)}$ ，わが国では肝 硬変症, NS, 熱傷, 出血性ショックに対し保険適応が なされている。

これまで成人肝硬変や少数のネフローゼ症候群患者を 対象としたrHSA 製剂の投与報告は散見されるもの $の^{2)}$ ，小児患者を対象とした投与報告はなされていな い。今回，当施設での小児ネフローゼ症候群患者に対す る rHSA の使用経験を概説する5)。

Key words : 遺伝子組換え人血清アルブミン製剂 ヒト献血由来アルブミン製剂 ピキア酵母 小児ネフローゼ症候群 


\section{対象・方法}

2008年 9 月から2009年 1 月に当科入院のネフローゼ症 候群患者で本人・家族の同意が得られた 6 例 ( 6 17 歳)，延べ 8 例（1 例では異なる入院時に計 3 回の投与 機会が得られた)。原疾患の内訳は, 微小変化型 3 例， 巣状系球体硬化症 2 例, 紫斑病性腎炎 1 例。浮腫，尿量 低下，循環不全をきたし，利尿剂のみでは症状の改善が 得られない状態。血清アルブミン濃度3 $.0 \mathrm{~g} / \mathrm{d} \ell$ 以下を投 与開始基準とし，当施設倫理委員会の承認を得た上で投 与を開始とした。

投与方法は, rHSA 25\%製剂を 1 時間で点滴静脈内投 与 ( 1 回最大 1 バイアル12 $5 \mathrm{~g}: 50 \mathrm{~m} \ell)$ ，投与前には血 清抗ピキア酵母 IgE 抗体陰性を確認した（陽性の場合は 原則投与を避(る計画とした)。また，実際の投与に当 たっては重篤なアレルギー反応，アナフィラキシー反応 に備え，適切なモニタリング，緊急処置・薬斉の準備を 行った。本剂の有用性をみる臨床検討項目は，投与前と 投与後 3 日目の体重, 血清総蛋白濃度, 血清アルブミン 血中濃度として投与前後で比較した。また，投与前後 3 日間の平均 1 日尿量の比較も行った。今回の検討の主目 的である安全性に関しては，本斉投与に伴うアレルギー 反応，アナフィラキシー症状等の有無，血清抗ピキア酵 母 IgE 抗体値の変化, 血中尿素窒素値 (BUN) と血清ク レアチニン值の変化を確認した55。

\section{結＼cjkstart果}

ネフローゼ症候群を呈した 6 名 , 8症例の内訳を表 1 に示した。対象は男子 7 例，女子 1 例，年齢平均は12 5 歳 ( 6 １7歳)，投与期間は平均11日間（3～22日間) であった。投与量は1日最小で $4 \mathrm{~g}$ 最大で $37.5 \mathrm{~g}$ と なった。入院初日から本剂が投与されたために投与前の 尿量測定ができなかったものでは，弚の項目のみ評価か ら除外した。今回の検討では，症例数が少なく投与方法 にもばらつきが大きいため，有意差は得られなかったも のの全症例において浮腫の改善，尿量の増加，体重の減 少, 血清総蛋白とアルブミン值の改善が確認された（表 2 )。本剂へのアレルギー反応に関しては，全例ですべ ての投与機会においてアレルギー反応等の副反応は認め られず，安全に投与することができた。すべての症例に おいて血清抗ピキア酵母 IgE 抗体值を本剂投与後 1 4 カ月間にわたり経時に測定したが，抗体の陽転化を示

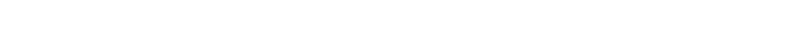
初回の投与機会において投与前後でBUN が $19 \mathrm{mg} / \mathrm{d} l$ か ら26mg/d $\ell$ ，血清クレアチニン值が0 $4 \mathrm{mg} / \mathrm{d} \ell$ から0 .9

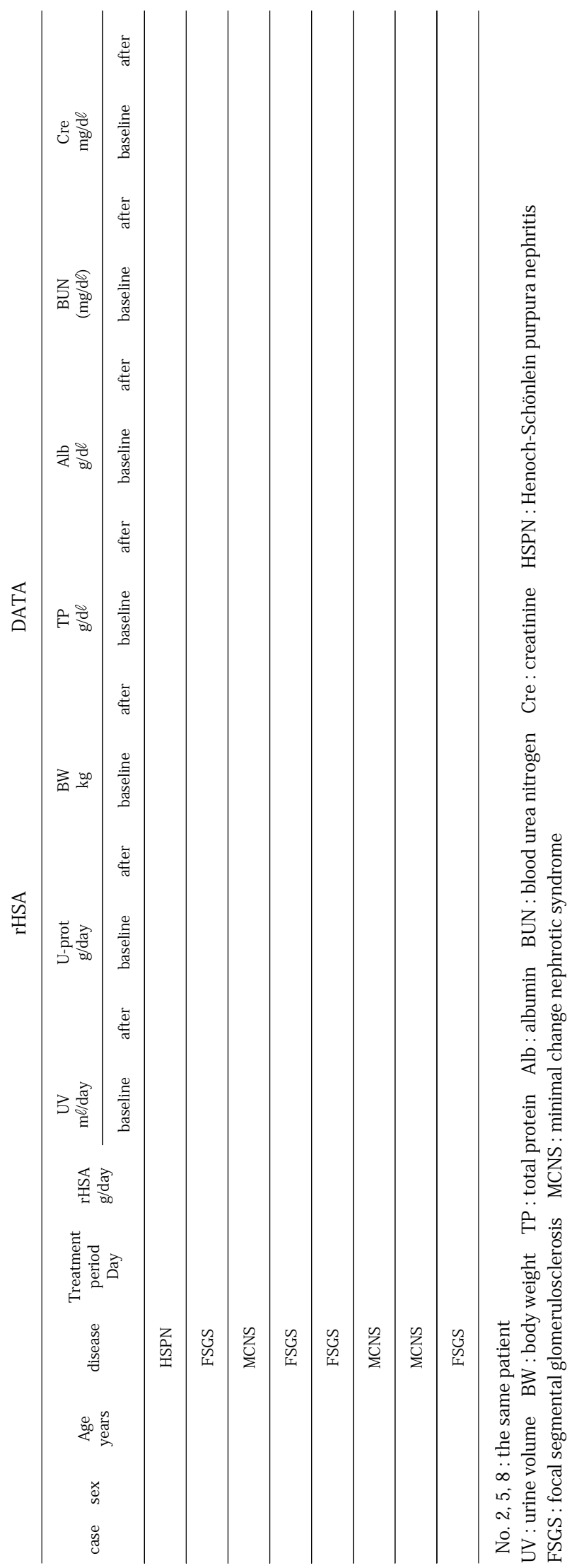


日览腎誌 Vol 22 No 2

表 2 投与前後での各比較項目の検討

\begin{tabular}{|c|c|c|c|}
\hline variable & base line & after & P-value \\
\hline Urine volume $(\mathrm{m} \ell)$ & $1561 \pm 563(800 \sim 2300)$ & $1669 \pm 660(500 \sim 2600)$ & 0834 \\
\hline Urine protein (g/day) & $103 \pm 5.9(31 \sim 21.0)$ & $112 \pm 8.5(4.4 \sim 28.7)$ & 0.497 \\
\hline Body weight (kg) & $44.6 \pm 151(15.4 \sim 608)$ & $431 \pm 14.6(143 \sim 57.7)$ & 0.529 \\
\hline Total Protein $(\mathrm{g} / \mathrm{d} \ell)$ & $4.7 \pm 0.4(3.9 \sim 52)$ & $48 \pm 1.0(3.4 \sim 6.5)$ & 0.713 \\
\hline Albumin $(\mathrm{g} / \mathrm{d} \ell)$ & $2.4 \pm 0.5(1.6 \sim 3.3)$ & $28 \pm 08(1.7 \sim 4.4)$ & 0.316 \\
\hline BUN $(\mathrm{mg} / \mathrm{d} \ell)$ & $13.4 \pm 52(8 \sim 21)$ & $16.0 \pm 5.7(10 \sim 24)$ & 0186 \\
\hline Creatinine $(\mathrm{mg} / \mathrm{d} l)$ & $0.45 \pm 0.15(02 \sim 0.6)$ & $0.51 \pm 016(0.3 \sim 0.7)$ & 0.420 \\
\hline
\end{tabular}

$\mathrm{mg} / \mathrm{d} \ell$ 入上昇か認められた。しかし，これらの変動は光 の後の経過観察中に速やかに正常化し，再投与の機会に おいて異常変動は認められなかった5)。

\section{考察}

NS における浮腫出現は, 尿中へ大量のアルブミンを 中心とする蛋白の漏出により低アルブミン血症となり， 膠質浸透圧の低下によって血管外へ水分が漏出し間質へ 貯留することが主要因となる。さらに循環血液量の減少 により，レニン-アンギオテンシン-アルドステロン系が 賦活化されナトリウムの再吸収が助長される。光のため 体内へのナトリウム貯留により全身の浮腫, 胸水, 腹水 貯留出現へつながってゆく。この際，ループ利尿剂が治 療に用いられることが多いが, 効果が不十分な場合，利 尿剂に加えアルブミン製剂を補充することによって血管 内容量を回復させ , 循環動態を安定化させることが浮腫 の軽減に有用とする報告もある6)。

現在, nHSA 製剂は肝硬変, NS, 熱傷, ショック等の 治療に広く用いられている。しかし, 献血由来であるが ゆえに未知のウイルスやプリオン等の感染症のリスクは 避けることが出来ない。一方, rHSA 製剂はピキア酵母 を宿主として作られ，動物由来の物質を一切用いておら ず感染症のリスクがない。nHSA 製剂との構造上の同一 性も確認されている7)-9)。製造に当たって宿主として用 いられるピキア酵母は, 味噌などの表面にも存在し , パ ン酵母である Saccharomyces cerevisiae と同樣の出芽酵 母であり，遺伝子組換え医薬品の宿主としての使用実績 もある。米国での開発治験において，血清抗ピキア酵母 IgE 抗体陽性の健常人に治験薬を投与したところ，アレ ルギー性の重篤な副作用が認められたという報告があ る。しかし，弚の後はアレルギー反応の誘発原性を低減 化するための製造方法の変更が実施されており，日本国 内での臨床試験においては, 血清抗ピキア酵母 IgE 抗体
陽性者と陰性者の間には副作用の発現率の比較では有意 差を認めなかったとされる。しかし，安全のために，製 斉の投与前には全例に血清抗ピキア酵母 IgE 抗体検査を 行う必要がある。陽性の場合は原則として投与は禁忌と なる。抗体検査はコマーシャルベースでの測定も可能で あり月 1 回の保険請求も可能となっている。また，イム ノクロマト法による検査では約40分での結果判定が可能 である。

われわれの使用経験では，今回検討した 6 人全員にお いて本剂投与前の血清抗ピキア酵母 IgE 抗体は陰性で あった。この内，1例の巣状系球体硬化症の患者は計 3 回の繰り返し投与を受けたがアレルギー反応はみられな かった。一方, 検討症例以外の微小变化型 NS の 1 例で 抗体が擬陽性であったため，rHSA 製剂の投与は行わ ず，従来からの nHSA 製剂を投与した症例があった。

$$
\text { 結論 }
$$

rHSA は，小児NS の患者に対し安全に投与でき，従 来の nHSA の代替療法として施行可能であることが示唆 された。他疾患に対しても rHSA は有効である可能性が あるが , 多数の症例を対象としたより長期間での検討が 必要である。

「日本小児腎藏病学会の定める基準に基づく利益に関す る開示事項はありません。」

$$
\text { 文献 }
$$

1 ) Matejtschuk P, Dash C H, Gascoigne W : Production of human albumin solution : a continually developing colloid. $\mathrm{Br}$ J Anaesth $85: 887-895,2000$

2 ) Kobayashi K : Summary of recombinant human serum albumin development. Biologicals $34: 55-59,2006$.

3 ) Kasahara A, Kita K, Tomita E, Toyota J, Imai Y, Kumada H : Repeated administration of recombinant human serum albumin caused no serious allergic reactions in patients with liver cirrho- 
sis : a multicenter clinical study. J Gastroenterol $43: 464-472$ 2008.

4 ) Ohnishi K, Kawaguchi A, Nakajima S, Mori H, Ueshima T:A comparative pharmacokinetic study of recombinant human serum albumin with plasma-derived human serum albumin in patients with liver cirrhosis. J Clin Pharmacol 48:203-208, 2008.

5 ) Tsuruga $\mathrm{K}$, Oki E, Yashiro T, Ito E, Tanaka H : Use of recombinant human serum albumin in pediatric patients with nephrotic syndrome. Pediatr Nephrol; DOI 10.1007/s00467-009-1221-y, 2009.

6 ) Dhamarji R, Hari P, Bagga A : Randomized cross-over trial comparing albumin and frusemide infusions in nephrotic syndrome.
Pediatr Nephrol $24: 775-782,2009$.

7 ) Ohtani W, Nawa Y, Takeshima K, Kamuro H, Kobayashi K, Ohmura $T$ : Physicochemical and immunochemical properties of recombinant human serum albumin from Pichia pastoris. Anal Biochem 256:56-62, 1998.

8 ) Ikegaya K, Hirose M, Ohmura T, Nokihara K : Complete determination of disulfide forms of purified recombinant human serum albumin, secreted by the yeast Pichia pastoris. Anal Chem 69 : 1986-1991, 1997.

9 ) Sugio S, Kashima A, Mochizuki S, Noda M, Kobayashi K : Crystal structure of human serum albumin at $2.5 \mathrm{~A}$ resolution. Protein Eng $12: 439-446,1999$.

\author{
Use of recombinant human serum albumin \\ in pediatric patients with nephrotic syndrome \\ Department of Pediatrics, Hirosaki University School of Medicine \\ Kazushi Tsuruga, Tomomi Yashiro, E ishin Oki, Hiroshi Tanaka
}

\begin{abstract}
Although recombinant human serum albumin ( $\mathrm{rHSA}$ ) has been recently developed from Pichia pastoris without using any animal-derived materials, its clinical use is yet limited especially in pediatric patients. We report our preliminary experience regarding the safety of rHSA in selected patients with nephrotic syndrome (NS). For the controlling refractory edema caused by NS, rHSA in combination with loop diuretics was administred to 6 NS patients, including one patient who received rHSA 3 times at every other month, from September 2008 to January 2009 in our hospital. One treatment course of rHSA was performed at least 3 consecutive days (3-22 days). Specific IgE antibody titers against Pichia yeast components measured before and after treatment remained negative all the study subjects. No allergic adverse events were observed. On the basis of changes in serum albumin level, urinary output, edema and body weight, the clinical usefulness seemed to be similar to that of conventional plasma-derived human serum albumin, as postulated in recent reports concerning the successful treatment of adult liver cirrhosis using rHSA. Our preliminary experience suggest that the safety and clinical usefulness of rHSA in the treatment of pediatric patients with NS. F urther studies to confirm the long-term safety and clinical usefulness of rHSA in a large number of patients are, however, needed.
\end{abstract}

Key words : Recombinant human serum albumin, Native human serum albumin, Pichia pastoris, Pediatric patients, Nephrotic syndrome 